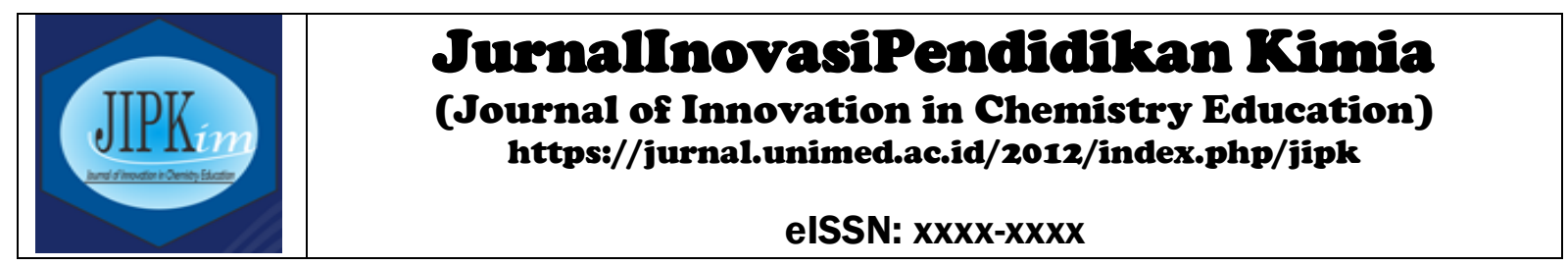

\title{
Analisis Butir Soal Ujian Semester Ganjil Kimia Kelas X SMA Negeri 1 Perbaungan
}

\author{
Ria Atika Br Purba ${ }^{\mathrm{a}, *}$, Nora Susantia ${ }^{\mathrm{a}}$, dan Rosna ${ }^{\mathrm{a}}$ \\ a Jurusan Pendidikan Kimia, Universitas Negeri Medan, Medan \\ *Alamat Korespondensi: email@institusi.ac.id
}

\begin{abstract}
:
The purpose of this study is to find out the quality of the odd chemistry semester exam questions of class X IPA 1 Perbaungan 2017/2018 school year based on qualitative analysis (material, construction, and language), analysis of cognitive level distribution, and quantitative analysis (validity, reliability, power difference, level of difficulty, and effectiveness of deception) using the ANATES V4 program. This study uses a type of quantitative research with descriptive methods. The results of this study are that the content validity in the material is in a very high category, in the construction aspect in the low category and the language aspect in the category is very high. Results based on cognitive domain level distribution are not in accordance with domain level proportions. The results of the study are based on quantitative analysis which is based on validity is $55 \%$ valid, and $45 \%$ is invalid. Based on reliability is 0.76. Based on the difference in power is good and based on effectiveness the deception is effective.
\end{abstract}

Keywords: Question Analysis, Qualitative Analysis, Quantitative Analysis

\section{PENDAHULUAN}

Pendidikan merupakan sarana untuk mencapai kesuksesan bagi setiap orang. Suatu Negara dapat dikatakan maju apabila memperhatikan pendidikan bangsa. Menurut Quisumbing (2003), kualitas pendidikan adalah proses yang bersifat dinamik, tidak statis dan bukan berupa produk akhir. Kualitas pendidikan selalu dilihat pada kemampuan lulusan suatu jenjang pendidikan, mulai dari sekolah dasar, sampai pada perguruan tinggi. Kemampuan lulusan yang juga sering disebut dengan kompetensi lulusan adalah kemampuan melakukan suatu tugas atau pekerjaan. Kemampuan ini terdiri atas aspek pengetahuan, aspek keterampilan, dan aspek perilaku.Untuk mengetahui seberapa jauh potensi yang telah dikembangkan peserta didik, diperlukan evaluasi.

Purwanto (2014) mengemukakan evaluasi adalah upaya sistematis cermat untuk memahami kemampuan dan kemajuan siswa baik sebelum, selama, maupun setelah proses pembelajaran, melalui pengumpulan data, serta membandingkan dengan norma atau kriteria tertentu. Menurut Zainal Arifin (2014) dalam dunia pendidikan, salah satu kompetensi yang harus dikuasai oleh guru adalah evaluasi pembelajaran. Kompetensi ini sejalan dengan tanggungjawab guru dalam pembelajaran yaitu mengevaluasi pembelajaran termasuknya adalah melaksanakan penilaian dan hasil belajar dan instrumen kemampuan guru, salah satu indikatornya adalah melakukan evaluasi pembelajaran.

Tes hasil belajar adalah tes yang digunakan untuk melihat hasil pelajaran yang telah diberikan oleh Guru kepada peserta didik dalam jangka waktu tertentu. Dalam melaksanakan hasil belajar, seorang guru dapat menggunakan dua macam tes yaitu tes yang sudah distandarisasikan dan tes buatan guru itu sendiri. Tes yang akan dilaksankan dalam penelitian ini adalah tes buatan guru itu sendiri. Tes tersebut belum mengalami proses standarisasi. Tes dapat dikatakan 
berkualitas, apabila dalam penyusunan soal tes memerhatikan validitas, reliabilitas, tingkat kesukaran, daya pembeda, efektivitas pengecoh, serta kesesuaian soal dengan standar kompetensi dan kompetensi dasar. Selain itu, penyusunan soal juga harus memerhatikan distribusi jenjang ranah kognitifnya, meliputi: didalamnya kemampuan menghafal (C1), memahami (C2), Mengaplikasi (C3), Menganalisis (C4), Mensintesis (C5), dan kemampuan mengevaluasi (C6). Berdasarkan penjelasan tersebut, dapat disimpulkan bahwa kualitas tes sangat penting untuk diperhatikan, karena kualitas tes akan dijadikan sebagai bahan pertimbangan dalam pengambilan keputusan hasil belajar peserta didik. Dengan demikian, sebelum soal-soal tes diberikan kepada peserta didik, guru harus mengetahui kualitas soal-soal tersebut melalui kegiatan analisis butir soal.

Penelitian analisis butir soal telah banyak dikaji dan dilakukan. Hal tersebut masih menarik untuk diadakan penelitian lebih lanjut, baik yang bermaksud melengkapi maupun yang baru. Analisis butir soal sangat bermanfaat bagi dunia pendidikan khususnya di bidang evaluasi pendidikan. Oleh karena itu, penulis tertarik untuk melakukan penelitian tentang analisis butir soal yang berjudul Analisis Butir Soal Ujian Semester Ganjil Kimia Kelas X SMA Negeri 1 Perbaungan Tahun Ajaran 2017/2018.

\section{METODE}

Penelitian ini menggunakan jenis penelitian kuantitatif dengan metode deskriptif yang bersifat ex-post facto, artinya tidak nelakukan manipulasi terhadap gejala yang diteliti dan gejalanya secara wajar sudah ada dilapangan (Nazir, 2005). Penelitian ini dilaksanakan di kelas X IPA SMA Negeri 1 Perbaungan. Populasi dalam penelitian ini adalah seluruh soal ujian akhir semester ganjil kimia di SMA Negeri 1 Perbaungan kelas X, XI, XII. Pada penelitian ini sampel yang diambil adalah seluruh populasi yang memenuhi persyaratan yaitu soal ujian semester ganjil kimia kelas X SMA Negeri 1 Perbaungan Tahun Ajaran 2017/2018.

Teknik pengumpulan data dalam penelitian ini yaitu waawancara dan dokumentasi. Dalam pengumpulan data, peneliti akan menggunakan alat untuk mempermudah dalam memperoleh data. Alat pengumpulan data yang digunakan yaitu daftar pertanyaan wawancara, dan daftar cocok (checklist). Penelitian ini menggunakan teknik analisis data secara kuantitatif. Teknik analisis data yang digunakan untuk menganalisis butir-butir soal ujian dengan mencari validitas, reliabilitas, daya pembeda, tingkat kesukaran dan efektivitas pengecoh (distractor).

Prosedur penelitian ini yaitu:

1. Tahap Persiapan meliputi observasi, menentukan populasi dan sampel, menyususn pertanyaan wawancara.

2. Tahap Pelaksanaan meliputi wawancara, meminta dokumen berupa kisi-kisi soal, soal ujian semester ganjil kimia, kunci jawaban, lembar jawaban siswa.

3. Tahap pengolahan Data meliputi analisis distribusi jenjang ranah kognitif, analisis kualitatif, dan analisis kuantitatif yang menggunakan program ANATES V4.

\section{HASIL DAN PEMBAHASAN}

\section{Analisis Materi, Konstruksi, dan Bahasa}

Analisis materi, konstruksi, dan bahasa untuk mengetahui validitas isi pada soal ujian semester ganjil pelajaran Kimia kelas X SMA Negeri 1 Perbaungan tahun ajaran 2017/2018. Kegiatan analisis tersebut dilakukan oleh dua penelaah, yaitu Pak Freddy T.M Panggabean, S.Pd, M.Pd (Penelaah 1 ) dan Ria Atika Br Purba selaku peneliti (Penelaah 2). Hasil analisis dari kedua penelaah selanjutnya dispesifikasikan menggunakan skala empat-point. Hasil skala empat-point kemudian dikategorikan menjadi dua jenis yaitu relevansi lemah dan kuat. Selanjutnya, skala empat-point yang telah dikategorikan tersebut, digunakan sebagai data untuk mengisi model kesepakatan interrater. Data dari kesepakatan interrater kemudian dimasukkan ke dalam rumus validitas isi. Berikut adalah perhitungan 
validitas isi berdasarkan aspek materi, konstruksi dan bahasa.

1. Berikut perhitungan validitas isi berdasarkan aspek materi

Validitas isi $=\frac{D}{A+B+C+D}$

$$
\frac{33}{7+0+0+33}=0.82
$$

2. Berikut perhitungan validitas isi berdasarkan aspek konstruksi

Validitas isi $=\frac{D}{A+B+C+D}$

$$
\frac{9}{31+0+0+9}=0.225
$$

3. Berikut perhitungan validitas isi berdasarkan aspek bahasa

$$
\begin{aligned}
\text { Validitas isi }= & \frac{D}{A+B+C+D} \\
& \frac{39}{0+1+0+39}=0.975
\end{aligned}
$$

Hasil perhitungan validitas isi selanjutnya dikategorikan berdasarkan kriteria validitas isi. Berikut tabel kriteria validitas isi:

Tabel 1. Kriteria Validitas Isi

\begin{tabular}{lcc}
\hline No. & Kriteri Validitas Isi & Kategori \\
\hline 1. & $0,80-1,00$ & Sangat Tinggi \\
2. & $0,60-0,79$ & Tinggi \\
3. & $0,40-0,59$ & Cukup \\
4. & $0,20-0,39$ & Rendah \\
5. & $0,00-0,19$ & Sangat Rendah \\
\hline
\end{tabular}

Jadi, validitas isi pada soal ujian semester ganjil mata pelajaran kimia kelas X SMA Negeri 1 Perbaungan pada aspek materi berkategori sangat tinggi, pada aspek konstruksi berkategori rendah dan pada aspek bahasa berkategori sangat tinggi

\section{Analisis Distribusi Jenjang Ranah Kognitif}

Analisis distribusi jenjang ranah kognitif telah dilakukan dengan cara mencocokkan butir soal dengan kategori proses kognitif Taksonomi Bloom (1956) yang direvisi oleh Anderson dan Krathowls (2001) dalam Kuswana (2012).Arifin (2012) menyatakan bahwa perbandingan soal yang baik adalah $30 \%$ soal mudah untuk $\mathrm{C} 1$ dan C2: $40 \%$ soal sedang untuk C3 dan C4: $30 \%$ soal sulit untuk C5 dan C6.

Berikut hasil persentase analisis distribusi jenjang ranah kognitif pada soal pilihan ganda ujian semester ganjil pelajaran kimia kelas X SMA Negeri 1 Perbaungan tahun ajaran 2017/2018 dibawah ini.

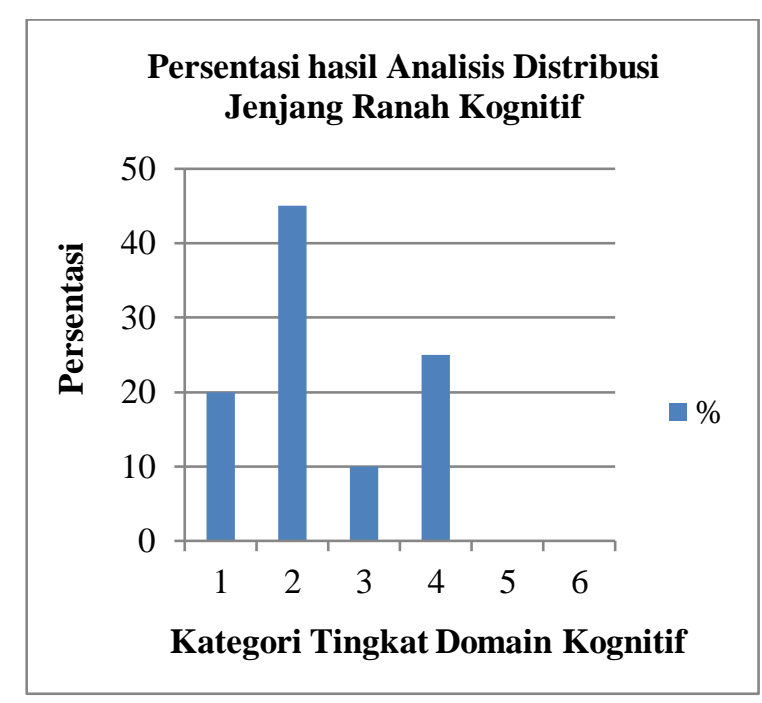

Gambar 1. Persentasi Analisis Distribusi Jenjang Ranah Kognitif

Berdasarkan Gambar 1. diperoleh informasi bahwa soal Ujian Semester Ganjil mata pelajaran Kimia kelas X SMA Negeri 1 Perbaungan memiliki $8 \quad(20 \%)$ soal berkategori mengingat ( $\mathrm{C} 1), 18(45 \%)$ soal berkategori memahami (C2), $4(10 \%)$ soal berkategori menerapkan (C3), dan 10 (25\%) soal berkategori menganalisis (C4).

\section{ANALISIS KUANTITATIF}

Analisis kuantitatif merupakan kegiatan analisis butir soal secara empirik yang didasarkan pada lembar jawaban siswa terhadap soal. Salah satu tujuan utama pengujian butir-butir soal secara emperik adalah untuk mengetahui sejauh mana masing-masing butir soal membedakan antara mereka yang tinggi kemampuannya dalam hal yang didefinisikan oleh kriteria dari mereka yang rendah kemampuannya. Sebagaimana telah disebut sebelumnya, bahwa item tes yang baik adalah item yang memenuhi syarat sebagaimana kriteria atau 
karakteristik item tes yang baik. Karakteristik item yang dimaksud adalah Validitas, Reliabilitas, Tingkat Kesukaran, Daya Pembeda, dan Efektivitas Pengecoh. Uraian Selengkapnya sebagai berikut.

\section{Analisis Validitas}

Dalam prosedur validasi berdasar kriteria (Criterion-related validity), tes yang akan diestimasi validitas hasil ukurnya disebut sebagai prediktor. Statistik yang digunakan dalam pendekatan validasi ini adalah statistikkorelasi antara distribusi skor tes sebagai prediktor dan distribusi skor suatu kriteria yang relevan. (Saifuddin Azwar, 2014 ). Analisis validitas dalam penelitian ini dilakukan menggunakan program komputer Anates V4 dengan teknik korelasi point biseral $\left(\mathrm{r}_{\mathrm{pbi}}\right)$.

Berikut hasil persentasi analisis validitas pada soal ujian semester ganjil kimia.

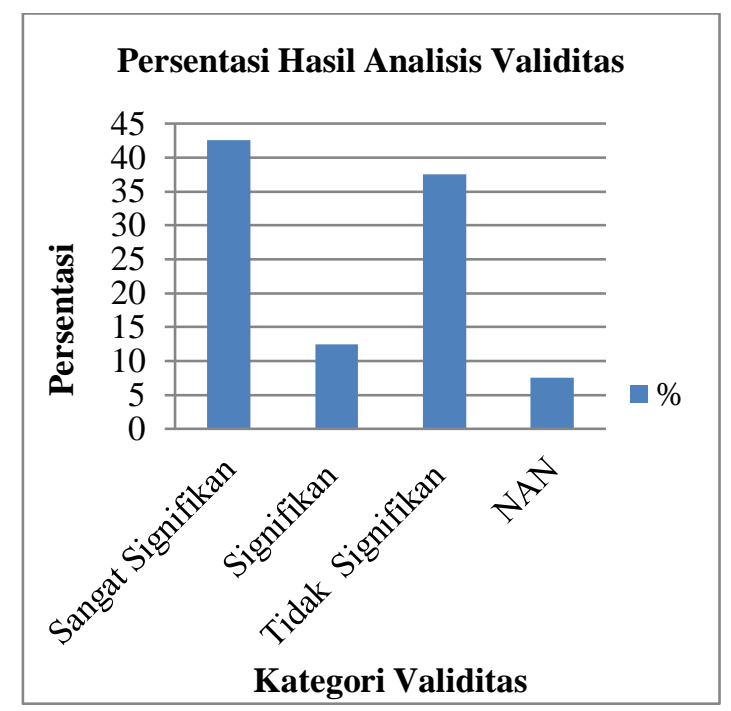

Gambar 2. Persentasi hasil Analisis Validitas

Jadi hasil analisis validitas soal Ujian Semester Ganjil Kimia kelas X SMA Negeri 1 Perbaungan, yaitu $17(42,5 \%)$ soal berkategori sangat signifikan, $5(12,5 \%)$ soal berkategori signifkan, $15(37,5 \%)$ soal berkategori tidak signifikan dan $3(7,5 \%)$ soal berkategori NAN.

\section{Analisis Reliabilitas}

Suatu tes dapat dikatakan memiliki taraf reliabilitas yang tinggi jika tes tersebut diujikan dalam kurun waktu yang berbeda dapat memberikan hasil yang tetap.
Reliabilitas yang tinggi ditunjukkan dengan nilai 1.00 , reliabilitas yang dianggap sudah cukup memuaskan atau tinggi adalah $\geq 0.70$. ( Daryanto, 2001).

Analisis reliabilitas dalam penelitian ini dilakukan menggunakan program komputer Anates V4. Koefisien reliabilitas soal Ujian Semester Ganjil mata pelajaran Kimia kelas X SMA Negeri 1 Perbaungan yaitu 0,76. Jika diinterpretasikan dengan batasan menurut teori, maka koefisien reliabilitas soal tersebut tergolong baik atau reliabel. Berdasarkan hasil analisis tersebut, dapat disimpulkan bahwa soal Ujian Semester tersebut reliabel, sehingga dapat digunakan berulang kali.

\section{Analisis Tingkat Kesukaran}

Menurut Whiterington, angka indeks kesukaran item tersebut besarnya berkisar antara 0,00 sampai dengan 0,01. Artinya angka indeks kesukaran paling rendah adalah 0,00 dan paling tinggi adalah 1,00. Angka indeks 0,00 merupakan petunjuk bagi tester bahwa item butir-butir tes hasil belajar tersebut terlalu sukar. Sebaliknya, jika angka indeks 0,01 merupakan bahwa butir item yang bersangkutan terlalu mudah.

Berdasarkan hasil analisis tingkat kesukaran yang dimiliki soal Ujian Semester ganjil mata pelajaran kimia kelas X SMA Negeri 1 Perbaungan, di peroleh $4(10 \%)$ soal berkategori sangat mudah, $2(5 \%)$ soal berkategori mudah, $27(67,5 \%)$ soal berkategori sedang, dan $7(17,5 \%)$ soal berkategori sukar.

Berikut hasil persentasi analisis tingkat kesukaran pada soal ujian semester ganjil kimia 


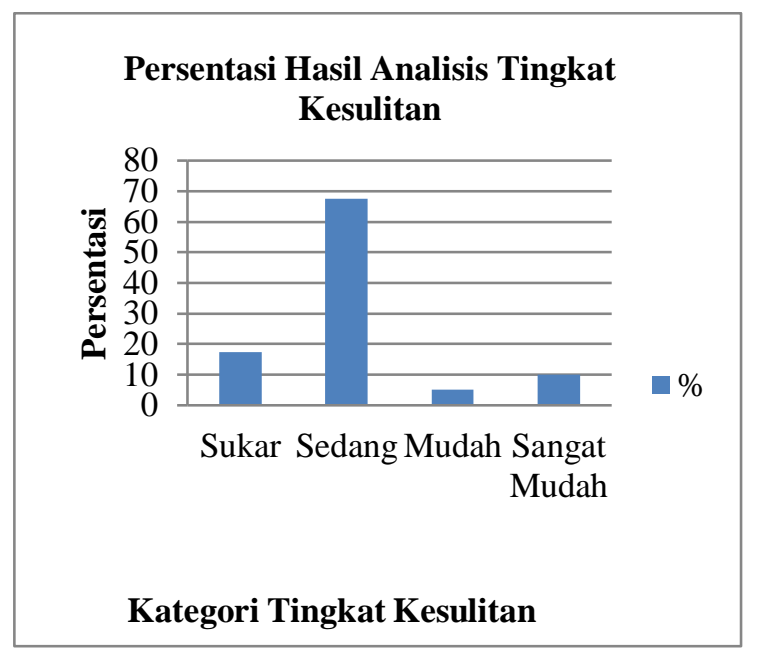

Gambar 3. Persentasi hasil Analisis Tingkat Kesukaran

\section{Analisis Daya Beda}

Daya pembeda dapat diketahui dengan melihat besar kecilnya angka indeks deskriminasi item. Angka indeks diskriminasi item adalah sebuah angka atau bilangan yang menunjukkan besar kecilnya daya pembeda yang dimiliki oleh sebutir item. Daya pembeda pada dasarnya dihitung atas dasar pembagian testee ke dalamdua kelompok, yaitu kelompok atas (kelompok yang tergolong pandai) dan kelompo bawah (kelompok yang tergolong bodoh) (Daryanto, 2001).

Berikut hasil persentasi analisis daya pembeda pada soal ujian kimia.

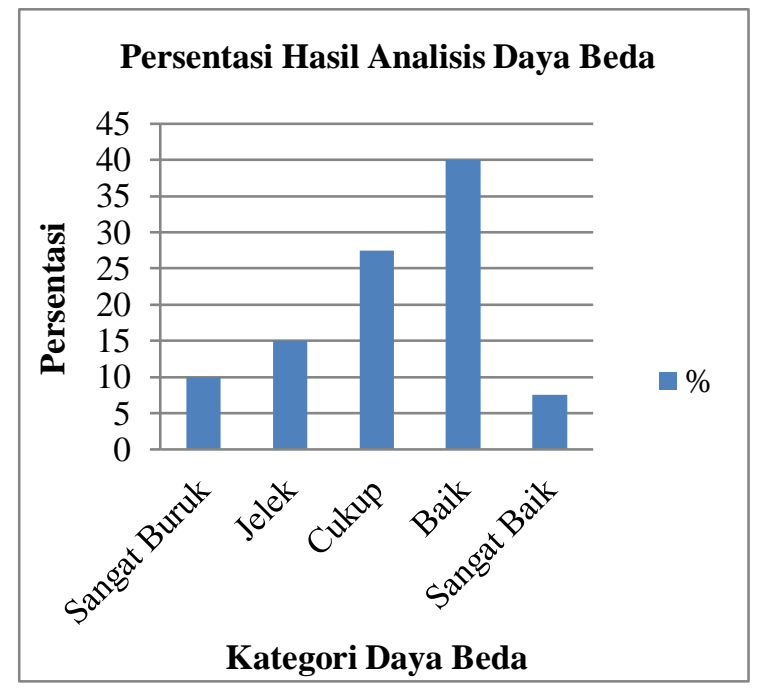

Gambar 4. Hasil persentasi Analisis Daya Pembeda

\section{Analisis Efektivitas Pengecoh}

Kelaziman yang berlaku dalam dunia evaluasi hasil belajar ialah, bahwa distractor dinyatakan telah dapa menjalankan fungsinya dengan baik apabila distractor tersebut sekurang-kurangnya sudah dipilih oleh 5\% dari seluruh peserta. Misalnya tes hasil belajar diikuti oleh 100 test. Distractor yang dipasang pada item tersebut dapat dinyatakan berfungsi apabila minimal 5 orang dari 100 testee sudah terkecoh untuk memilih distractor tersebut (Daryanto, 2001).

Jadi dapat disimpulkan bahwa pengecoh dikatakan baik apabila masingmasing pilihan jawaban dipilih oleh minimal $5 \%$ siswa yaitu 7 siswa. Setelah hasil analisis dikategorikan, diketahui bahwa soal yang dianalisis efektivitas pengecohnya terdapat 24 soal soal berkategori efektif dan 16 soal berkategori tidak efektif.

Berikut hasil persentasi analisis efektivitas pengecoh

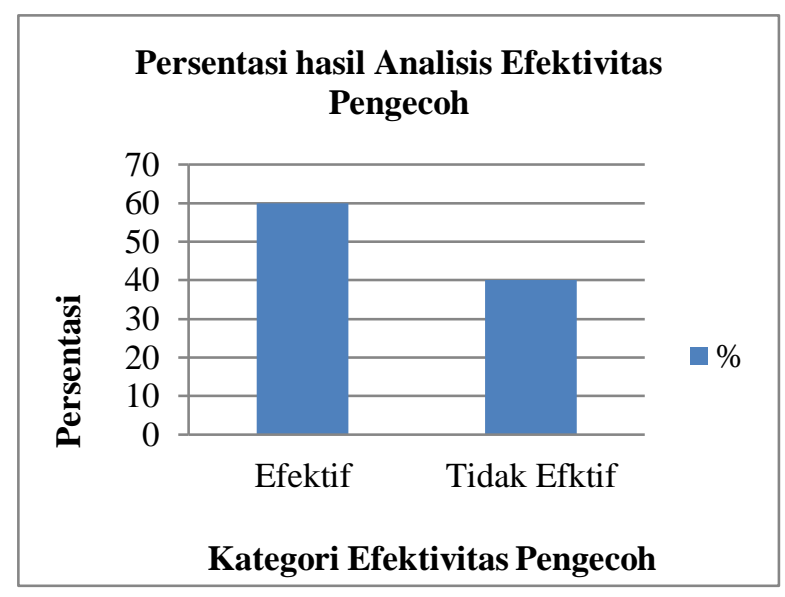

Gambar 5. Hasil persentasi analisis efektivitas pengecoh

Butir soal yang efektivitas pengecohnya tidak baik dan sangat tidak baik mengindikasikan bahwa pengecoh belum dapat berfungsi dengan baik, pengecoh tersebut tidak memiliki daya tarik bagis siswa yang kurang menguasai konsep atau materi ( Rahayu, $d k k, 2016$ ).

\section{KESIMPULAN}

Analisis validitas isi pada aspek materi berkategori sangat tinggi, pada aspek konstruksi berkategori rendah dan pada aspek bahasa berkategori sangat tinggi. Distribusi jenjang ranah kognitif yang 
terukur pada soal ujian yaitu $8(20 \%)$ soal berkategori $\mathrm{C} 1,18$ (45\%) soal berkategori C2, 4 (10\%) soal berkategori C3, dan 10 (25\%) soal berkategori C4. Kualitas soal ujian dari aspek validitas yaitu $17(42,5 \%)$ soal berkategori sangat signifikan, 5(12,5\%) soal berkategori signifkan, $15(37,5 \%)$ soal berkategori tidak signifikan dan $3(7,5 \%)$ soal berkategori NAN. Aspek reliabilitas diperoleh koefisien reliabilitas sebesar 0,76 dengan kriteria reliabel, karena lebih dari 0,70 . Aspek tingkat kesukaran yaitu $4(10 \%)$ soal berkategori sangat mudah, $2(5 \%)$ soal berkategori mudah, $27(67,5 \%)$ soal berkategori sedang, dan $7(17,5 \%)$ soal berkategori sukar. Aspek daya pembeda yaitu $3(7,5 \%)$ soal berkategori sangat baik, $16(40 \%)$ soal berkategori baik, $11(27,5 \%)$ soal berkategori cukup, 6 (15\%) soal berkategori jelek dan 4 (10\%) soal berkategori sangat buruk. Aspek efektivitas pengecoh yaitu 24 (60\%) soal berkategori efektif dan 16 (40\%) soal berkategori tidak efektif.

Pelaksanaan tes pada ujian semester ganjil mata pelajaran Kimia kelas X SMA Negeri 1 Perbaungan tergolong cukup baik, karena adanya faktor ruangan kelas yang tenang / kondusif dan posisi duduk yang teratur

\section{DAFTAR PUSTAKA}

Arifin, Zainal. (2014). Evaluasi Pembelajaran Prinsip Teknik Prosedur. Bandung: PT. Remaja Rosdakarya.

Azwar, Saifuddin. (2014). Reliabilitas dan Validitas edisi 4. Yogyakarta: Pustaka Pelajar.

Daryanto. (2001). Evaluasi pendidikan. Jakarta: PT Asdi Mahasatya

Kuswana, Wowo, S. (2012). Taksonomi Kognitif, Bandung: PT Remaja Rosdakarya.

Nazir. (2005). Metode Penelitian. Bogor: Ghalia, Indonesia.

Purwanto. (2014). Evaluasi Hasil Belajar. Yogyakarta: Pustaka Pelajar.

Rahayu, Rahmatika dan Djazari, M. (2016). Analisis Kualitas Soal Pra Ujian Nasional Mata pelajaran Ekonomi Akuntansi.
Jurnal Pendidikan Akuntansi Indonnesia. Vol 14(1), 8.

Quisumbing., Louders, R. (2003). Towards quality education for all - round human development. Paper presented at The $9^{\text {th }}$ Unesco-Apeid International Conference on Education. Shanghai China, 4-7 November, 2003. 